\title{
Company's Decision on Virtual Exhibition During Covid-19 Pandemic
}

\author{
'Pesta Elrida Lumbantoruan ${ }^{1}$, Wahyudi David ${ }^{2}$ \\ ${ }^{1}$ Prodi Magister Manajemen, Universitas Bakrie, Jakarta, Indonesia \\ 2 Prodi Ilmu dan Teknologi Pangan Universitas Bakrie, Jakarta, Indonesia \\ *Corresponding Author pestaelfrida96@gmail.com
}

\begin{abstract}
Article Info

Volume 8, Issue 4

Page Number : 207-215

Publication Issue

July-August-2021

\section{Article History}

Accepted : 06 July 2021

Published : 13 July 2021

The exhibition is one of the promotional tools that increase company branding, product brand as well as awareness of direct sales. Exhibitions are considered investment activities carried out by companies. During pandemic Covid-19, offline exhibitions are impossible to be hosted. As alternative to hosted exhibitions by using virtual or online platforms. However, there is still a need to study to evaluate which factors have a stronger influence and relationship on the exhibition decision. The data analysis method used is multinomial logistic regression analysis. The results showed that the quality of the exhibition, popularity, time, representation, and price determine the company's decision to join an exhibition. It concludes that the company's decision is influenced by these factors $65 \%$ and three factors are having a significant influence for joining the exhibition.
\end{abstract}

Keywords : E-Xhibition, Event, Virtual Exhibition, Decision

\section{INTRODUCTION}

The emerging of Coronavirus Disease in 2019, has impacted global economic the significant impact is Meeting, Incentive, Convention and Exhibition (MICE) industries as it is shown by the number of cancellations and postpones for the activities that involve crowds to prevent the spread of Covid-19 such doing the exhibition. This Coronavirus disease changes activities that were previously offline into online activities. Likewise with the MICE industry, especially exhibitions. One alternative to doing activities is by organizing virtual or online-based exhibitions to provide opportunities for all sectors to be able to carry out activities.

An exhibition is a promotional event that is participated by companies to do branding and direct sales for business to business (B2B), business to customer (B2C), and business to government (B2G). Known as an exhibition or other sort of an event organized, this industry not only gives good influence to the companies' branding but also the national economy growth, exactly the Gross Domestic Product (GDP). The Covid-19 which becomes pandemic to the whole world makes the MICE industries confront new challenges and figure out the possible chances.In 
taking advantage of existing opportunities, the exhibition association persuades all members to keep organizing some events in the pandemic seasons to help the clients to exhibit virtually. Thus they still do the promotions and increase their sales.

\section{A. EXHIBITION}

Exhibition is a meeting event held in a meeting room in which a group of producers or consumers are gathered from different segments (Kesrul, 2016). Also, Pudjiastuti (2010) states that exhibition is considered as a special event that is a most effective way to introduce products publicly and it is hopefully aimed the public to be interested in buying the products on display and as one of the most preferred special events by the trade companies for commercial purposes, the companies will join either in local, national or international exhibitions.

The benefits of an exhibition according to Lidia Eveline in Pudjiastuti (2010) are aimed to get the right information about a newly launched product by directly introducing it to consumers, strengthen company beyond the competitors and maintains the product image for the better understanding the public accomplishes about the positioning of goods and services of the company's products. Philip Kotler in Pudjiastuti (2010) state thats, the exhibitions considered the most effective tools of promotion because it can raise the image of a product or company and can see interactions and know firsthand the public's interest in the product or company where the product offered will be better known to the public by providing information as clearly as possible directly to the public about the product/company which will be able to change attitudes and opinions of the community related to the product or company.

Nowadays it is known that the development of the MICE industry, especially exhibitions, is growing rapidly, both business to business (B2B), business to customer (B2C), and business to government (B2G) exhibitions. As reported through the Asperapi on 2019 report, it is known that the exhibition in Indonesia has reached 200 large-scale exhibitions with more than 50 organizers. Organizing the exhibition involves many parties in its implementation, including contractors, advertising, venues, restaurants, and others. This also encourages the government to develop the MICE creative industry during the impact of the coronavirus pandemic. In line with technological developments, the development of industry 4.0 engages the implementation of MICE industry must begin to change from conventional events to hybrid events and events online.

\section{B. DECISION}

Decision-making is very important for organizations, the growth of an organization is influenced by the decision-maker, management of a company, or organization. Generally known that a decision means doing something new, the decision is aimed to perform changes and create new things concerning the visions and missions. The good decision is not ambiguous and not muddying through concepts or hasty decisions made with lack of information, fewer facts, and not well planned.

The decision is the conclusion of the choices that have been determined to be used based on the stages or processes. Morgan and Cerullo in Salusu (2015) defines a decision as a conclusion of considerations concerning one chosen possibility while putting the other side. The consideration is aimed to analyze and describe several possibilities/alternatives that will occur when the decision is made. According to Brinckloe (1977), a decision-maker must attentively focus on Facts and Experience. A decision-maker must be able to collect the facts related to the decision and must reflect on either the experience of decision making or the experience of occurs. 


\section{QUALITY OF EXHIBITION}

The quality of the exhibition is important for the sustainability of the organizer. Exhibition quality describes how an organization can give the expected value to the customers. The good quality of implementation at an exhibition has a positive impact on organizers, exhibitors, and parties who participate in the activities. The good quality of the exhibition will affect satisfaction, trust, and loyalty. Kotler (2005) states that customer satisfaction is the pleasures or the disappointments after comparing the predicted and expected results, in other words the reality as expected. Trust arises in the results and actions taken on something. In exhibitions, the quality and customer satisfaction will intensify the trust between the customer and the company. Customer trust in the company will have an impact on customer retention. Griffin in Setiawan (2011) assesses that customer loyalty is the more reliable measurement to predict marketing and financial growth than customer satisfaction. Dick and Basu in Setiawan (2011) conclude that customer loyalty is assessed based on the strong attitude and high frequency of consumers repeatedly purchasing and Zeithaml dan Bitner in Setiawan (2011) explains that the main reason for making a decision is the customer's perceptions of the service quality.

\section{POPULARITY OF EXHIBITION}

The popularity of an exhibition is measured by the success rate of organizing the exhibition, namely the number of visitors as expected, the well-organized promotional itinerary, and the benefits as customer expectations. The popularity is tightly related to superiority, the more popular an exhibition is, the more superior it becomes. The popular brands will impact the reputation. Fombrun in Abadi and Herwin (2018) states that reputation is the result of someone's experiences with goods and services they earn, the good reputation will increase the credibility triggering the customer trust in the products as the producer promises to meet the consumer expectations.

\section{E. REPRESENTATION}

The representation is concerned with the corporate identity. The corporate identity is shown by branding from the company itself. Branding is one of the keys of company success to make the company popular or the higher popularity, also to raise the quality of the company thus the good branding of a company will create brand awareness among the society. Giles and Middleton in Ahmad (2019) explains that the representation means to represent of which three definitions namely to stand in for, to speak or act on behalf of and to re-present.

\section{F. TIMING OF EXHIBITION}

Choosing the right time will be able to assist the company to set marketing strategies in accordance with its vision. Time is everything for promotion, the right time chosen determines the achievement of target promotions well. The appropriate timing to participate in exhibitions is one of the keys of success in integrated marketing communication in companies. It creates good synergy, coordination and relationship among the teams in order to raise the company's branding, brand awareness and boost the sales achievement of the company itself.

\section{G. PRICING}

Price is an exchange rate that is usually used to get goods and services of which values fit into the benefits. Price is the total values given by the customer to get the advantage by having or using the products either in terms of goods or services (Kotler, 2008). Companies participating in an exhibition must prepare an amount of funds to maximize the activities that are programmed and planned. Each capital fund has cost consequences either for withdrawing funds or the opportunity cost with return if only it is used for investment (Irfani, 2020). 


\section{METHODS}

\section{A. RESPONDENT}

In this study, the population of this research is seventy-two (72) participants of the IndoBuildTech Digital Fair. IndoBuildTech is an exhibition for building material, architect, and interior companies which is engaged in sanitary, ceramic, lighting, wood panels, 3D wall panels, roofing, water heater, pool, aluminum, building chemical, glass, and security system industries.

\section{B. DATA COLLECTION}

The data collection method in this research is using a questionnaire by using the Likert scale, which is a scale that shows the same values in the characteristics being measured (Sugiyono, 2016). This study uses census data research of which the entire population is used as the research sample.

\section{DATA ANALYSIS}

The data analysis in this study used Multinomial Logistic Regression Analysis. Multinomial Logistic Regression aims to figure out how independent variables impact the dependent variable. Besides, it becomes the basis tool to solve the problems of the research. Multinomial logistic regression analysis is used when the dependent variable has a polichotomial or multinomial scale, namely nominal and ordinal scales with more than two categories (Hosmer and Lemeshow, 2000). This study uses a logistic regression model with ordinal scale response variables. The logistic regression model is

$$
\begin{gathered}
\pi(x)=\frac{e^{g(x)}}{1+e^{g(x)}} \\
\text { with: } g(x)=\beta_{0}+\beta_{1} x_{1}+\cdots+\beta_{p} x_{p}
\end{gathered}
$$

\section{RESULT AND DISCUSSION}

\section{A. RESULT}

\section{Model Fitting Information}

Model Fitting Information is a test that will see the effect of all independent variables on the dependent variable. Testing is done by comparing the value between the initial 2-log likelihood (-2LL) and -2LL likelihood $(-2 L L)$ in the final model. The value reduction that occurs between the initial -2LL and the -2LL final model means that the model is a fit model (Ghozali, 2017).

Table 4.1 Model Fitting Information

\begin{tabular}{|c|c|c|c|c|}
\hline \multicolumn{5}{|c|}{ Model Fitting Information } \\
\hline \multirow{2}{*}{ Model } & Model Fitting & \multicolumn{3}{|c|}{ Likelihood Ratio Tests } \\
\cline { 2 - 5 } & -2 Log Likelihood & Chi-Square & df & Sig. \\
\hline Intercept Only & 325,118 & & & \\
\hline Final & 111,109 & 214,010 & 55 & 0,000 \\
\hline
\end{tabular}

The table shows that the initial -2LL value (intercept only) is 325,118 while the final -2LL value is 111.109 . This value shows a decrease in the -2 Log-Likelihood of 214.010 with a significant 0.000 . Thus the variables of quality, popularity, timing, representation and price more dominantly influence the company to participate in an exhibition than intercept only that it becomes a fit model. Based on the table, it is known that the independent variables simultaneously influence the dependent variable of which P-Value $<0.05$.

\section{Goodness of Fit Test}

The goodness of fit test is aimed to examine the congruence of the data with the model used.

Table 4.2 Goodness of Fit Test

\begin{tabular}{|c|c|c|c|}
\hline \multicolumn{4}{|c|}{ Goodness-of-Fit } \\
\hline & Chi-Square & df & Sig. \\
\hline Pearson & 177,163 & 616 & 1,000 \\
\hline Deviance & 109,382 & 616 & 1,000 \\
\hline
\end{tabular}

The table shows the value of statistic chi-square is 177,163 (Pearson) of which significant is 1,000 and 109,382 (deviance) of which significant is 1,000 and it is concluded that the multi-nominal logistic model is feasible to use because the $\mathrm{P}$-value $>0.05$.

\section{Pseudo R-Square}

Pseudo R-Square is used to determine the capability of independent variables for explaining the dependent 
variable and how well a model is able to explain the relationship between independent variables and the dependent variable.

Table 4.3 Pseudo R-Square

\begin{tabular}{|c|c|}
\hline \multicolumn{2}{|c|}{ Pseudo R-Square } \\
\hline Cox and Snell & 0,949 \\
\hline Nagelkerke & 0,959 \\
\hline McFadden & 0,653 \\
\hline
\end{tabular}

This research estimates the value of $\mathrm{R} 2$ ( $\mathrm{R}$ square) by using the Mcfadden value. Based on the table, it shows that the independent variables affect the dependent variables with percentage $65 \%$ influenced by the factors discussed in this research and 35\% influenced by other factors.

\section{Likelihood Ratio}

Likelihood ratio test used to see and describe the significance of contribution of each independent variable with dependent variable (Hosmer \& Lemeshow, 2000). The likelihood ratio describes the contribution of each independent variable to the dependent variable and based on the table, shows that representation, timing and pricing are the most significant factors influencing the company's decision to participate in the exhibition.

\section{Table 4.4 Likelihood Ratio}

\begin{tabular}{|c|c|c|c|c|}
\hline \multicolumn{5}{|c|}{ Likelihood Ratio Tests } \\
\hline \multirow{2}{*}{ Effect } & Model Fitting & \multicolumn{2}{|c|}{ Likelihood Ratio Tests } \\
\cline { 2 - 5 } & $\begin{array}{c}\text {-2 Log Likelihood } \\
\text { of Reduced Model }\end{array}$ & Chi-Square & df & Sig. \\
\hline Intercept & 224,810 & 113,701 & 11 & 0,000 \\
\hline Quality & 123,81 & 12,701 & 11 & 0,313 \\
\hline Popularity & 120,819 & 9,710 & 11 & 0,557 \\
\hline Timing & 132,515 & 21,407 & 11 & 0,029 \\
\hline Representation & 134,685 & 23,577 & 11 & 0,015 \\
\hline Price & 133,091 & 21,982 & 11 & 0,025 \\
\hline
\end{tabular}

This result is consistent with the report published by Kang J \& Schrier (2011) that companies that have experience in attending exhibitions, both small and large companies have a higher intention to joining virtual exhibitions. The exhibition can represent the company to the target groups of the expo, such as visitors and other companies participating in the expo or trade show. In addition, for exhibitions, the ability of the company to pay to participate or to pay for the stands and operating costs during the expo is very influential. The cost is related to the price set by the organizer, the financial situation of the companies, and the charge paid is in line with the benefits obtained and perceived during the exhibition.

\section{PARAMETER ESTIMATES}

Parameter estimates are used to see the value contribution of each independent variable to the dependent variable. Based on the value of the odds ratio or $\operatorname{Exp}(B)$ and the value of $B$, which is the regular logarithm of $\operatorname{Exp}(\mathrm{B})$, it explains that there are two independent variables that have positive values with the dependent variable and three independent variables have negative values with the dependent variable. The quality variable and the price variable have positive values with the decision variable and the popularity, time, and representation variables have negative values with the dependent variable, namely the decision variable.

Table 4.5 Parameter Estimates

\begin{tabular}{|c|c|c|c|c|c|c|c|c|}
\hline \multicolumn{9}{|c|}{ Parameter Estimates } \\
\hline \multirow[b]{2}{*}{ Decision } & \multirow[b]{2}{*}{ B } & \multirow[b]{2}{*}{ Std. Error } & \multirow[b]{2}{*}{ Wald } & \multirow[b]{2}{*}{ df } & \multirow[b]{2}{*}{ Sig. } & \multirow[b]{2}{*}{$\operatorname{Exp}(\mathbf{B})$} & \multicolumn{2}{|c|}{ 95\% Confidence } \\
\hline & & & & & & & $\begin{array}{l}\text { Lower } \\
\text { Bound }\end{array}$ & $\begin{array}{l}\text { Upper } \\
\text { Bound }\end{array}$ \\
\hline Intercept & 347,038 & 7793,222 & 0,002 & 1 & 0,964 & & & \\
\hline Quality & 10,603 & 375,337 & 0,001 & 1 & 0,977 & 1,198 & 0,518 & 2,772 \\
\hline Popularity & $-24,707$ & 436,470 & 0,003 & 1 & 0,955 & 1,069 & 0,337 & 3,393 \\
\hline Timing & $-14,168$ & 1118,243 & 0,000 & 1 & 0,990 & 0,086 & 0,002 & 3,074 \\
\hline Representation & $-1,492$ & 339,709 & 0,000 & 1 & 0,996 & 0,846 & 0,228 & 3,138 \\
\hline Price & 14,780 & 263,358 & 0,003 & 1 & 0,955 & 2,138 & 0,599 & 7,629 \\
\hline
\end{tabular}

The table above proves that a multinomial logistic regression equation can calculate the effect of the independent variable on the dependent variable. The following is the equation for the effect of the independent variable on the dependent variable: 


$$
P=\frac{e(347,038+10,603 X 1-24,707 X 2-14,168 X 3-1,492 X 4+14,780 X 5)}{1+e(347,038+10,603 X 1-24,707 X 2-14,168 X 3-1,492 X 4+14,780 X 5)}
$$

\section{B. DISCUSSION}

\section{Representation In Joining An Exhibition}

Representation is the description of a company to introduce itself to the public and competitors. Participating in an exhibition, companies of participants will be able to compete with competitors as the visitors can figure out the best match company or brand to deal with the business or any other interests through the representation and it reveals the company either has strong or weak branding. If a well-known company or big competitor does not participate in an exhibition, it becomes a factor that influences the participation of companies in the exhibition. Sallam (2016) states that representation has a big impact on a company brand. The impact is bringing the big brand image in the future for the sustainability of the company and give the positive effect in a strong relationship, good reputation, social responsibility and give a big effect for revenue. By attending or joining an expo, a company finally introduces their identity to the public and makes the value brand more famed.

The presentation is the company's brand image, which contains the perception and all information about the company or product. This brand image will be generated from how strong the company can promote the brand or the brand itself. Strong branding will lead to a more positive image where the company will be increasingly recognized by the general public. Evalina (2012) states that representation will provide consumers with a positive image of a brand that will lead to and also increase the use of goods and services. The exhibition is also the most effective promotion carried out, this is because exhibitions are a very broad meeting place between companies and companies, companies and consumers, companies with associations and with experts that will increase company value.

\section{Timing In Joining An Exhibition}

Timing is one of the considerations in deciding to participate in an exhibition because the false timing will hinder the participation in the exhibition. Time is tightly related to a certain condition on which the agenda meets the expected schedule by the company for promotion and marketing activities. UFI (2020) as a global exhibition association states that the conditions of the Covid-19 pandemic have a huge impact on the activities of the exhibition. Covid-19 makes the client re-consideration companies participating in exhibitions, clients expect to join the expo when the situation gets better and normally and expect in more face-to-face exhibitions to maximize company sales and can rebuild visitor euphoria to increase company turnover and company brands.

The Covid-19 pandemic has a major impact approaching the crisis in changing consumer behavior or habits in using products and services. Covid -19 caused companies to be extra concerned about the company's business and financial conditions. The company must be able to maintain the balance of the company's financial condition for business sustainability. The exhibition, which is one of the investments in promotion, in the conditions of the Covid-19 pandemic, companies are still able to carry out appropriate promotions but still consider conditions and circumstances so that the promotions invested will be under the targets expected by the company.

Timing is one of the most impactful for the company's advantages, for instance the current situation of pandemic Covid-19 pushes the companies to consider in advance to decide their promotion and marketing 
programs. This research is parallel to the result found by Solihat and Nugraha (2020) concerned with behavior financial during the pandemic. They found out that the current condition changes either personal or company patterns and styles to manage the budgeting in the capital, unemployment, and any other economic issues that are hoped to maximize the finance. The right investment expected needs to be supported by the finances of a company before deciding other programs that the company can keep the balance and profit with the investment.

\section{Price In Joining An Exhibition}

Price is one of the elements considered by the company to decide to participate in an exhibition because price becomes the value of the exhibition becomes the expectation of the company to participate in the exhibition. It is also known that the cost to participate in an exhibition significantly figures out the current financial condition and operational ability of the company. If the price is balanced to the current financial account, the company will decide to participate in the exhibition with the expectation that the benefits the company will earn pays off the price invested to join the exhibition. As stated by Dea (2019) that the financial condition of a company is equal to the performance of the company itself in other words every investment is so impactful and the decision to invest will give additional value to the good image of the company.

According to $\mathrm{Pu}$, Xiao and Dua (2019), exhibition prices also affect the relationship that will be built between exhibitors and organizers. The price offered must be fit with the benefits obtained during the exhibition. Furthermore, the exhibition organizers must be able to implement a pricing strategy, especially at the current time and in certain situations like price promotions or non-price promotions where later be able to increase the effectiveness of participants in increasing sales or increasing the company value brand.
Price is one element of the strategy that the company must be considered. Price decisions are the most important decisions of management because they will affect the probability of the value of the company. According to De Toni (2017), price is a strategic approach to determine the performance that a company will get with a more competitive development so that it can provide appropriate benefits. In addition, it is also mentioned that price is the element that most influences the performance of the company, with the right price, the company can map current customers and potential customers who will come to be able to provide benefits for the company

\section{v. CONCLUSION}

The analysis concluded that the factors that have a significant influence in deciding to participate in an exhibition are representation, timing, and price. This research found that the independent variables are $65 \%$ influencing the company to determine the decisions of the company participating in an exhibition. Regarding the research, it shows that the key to the decision of the company joining the exhibition/expo is the representation of the company. Representation brings more engagement and is able to reach more exposure to the market as long as the expo will make the company branding and more well-known by the society. Also, representation of the company will be able to increase relations with other parties. The exhibition's purpose is to encourage the company's strategies to achieve company aims.

\section{REFLECTION}

In closing, the reflection on this research is a strategy that companies need to have in participating in exhibitions. Through this research, it is hoped that the company will be able to pay attention to the points that have been explained in deciding to participate in exhibition activities. The exhibition as a promotional event that has more value is expected to 
be able to provide benefits that are by the wishes of every company participating in the exhibition to achieve the company's goals. In addition, it also reflects that exhibition organizers must be able to provide the same value to exhibitors under the goals desired by the companies to maintain relationships and also company loyalty to the organizers and preserve the name of the organizer and the name of the exhibition.

\section{LIMITATIONS}

This research is alaysized one virtual exhibition, therefore it could not represent the whole type of virtual exhibition. The development of the exhibition world will continue to improve and evolve. The implementation of a hybrid expo as offline and online in the future will become a new habit for organizers, exhibitors, and all third parties. Therefore, more research is needed to see other factors that can influence companies to participate in an exhibition or trade show.

\section{REFERENCES}

[1]. ASPERAPI. (2019). List Pameran 2019. Jakarta: Asperapi.

[2]. Bougie, U. S. (2016). Research Methods for Business, A Skill Approach Seventh Edition (7 ed.). United Kingdom: John Wiley \& Sons Ltd.

[3]. Dea Agustin Andrianingtyas, A. S. (2019, Juli). Pengaruh Kinerja Keuangan dan Keputusan Investasi Terhadap Nilai Perusahaan Dengan Kebijakan Dividen Sebagai Variabel Intervening. JEKPEND, 23-30.

[4]. De Toni, D., Milan, G. S., Saciloto, E. B., \& Larentis, F. (2017). Pricing strategies and levels and their impact on corporate profitability. Revista de Administração, 52(2), 120-133. https://doi.org/10.1016/j.rausp.2016.12.004

[5]. Ghozali. (2017). Aplikasi Analisis Multivariate Dengan Pogram IBM SPSS 23. Semarang: Universitas Diponegoro.333
[6]. Hery, S. R. (2019). Manajemen Pemasaran. Jakarta: PT Grasindo.

[7]. Hosmer, D. W., \& Lemeshow, S. (2020). Applied Logistik Regressiom (Second Edition ed.). America: John Wiley and Sons, INC.

[8]. Indrawati, P. R. (2019). Marketing for Non Marketing Superintendents. Jakarta: PT Elex Media Komputindo.

[9]. Irfandi, A. S. (2020). Manajemen Keuangan dan Bisnis. Jakarta: PT Gramedia Pustaka Utama.

[10]. John Foley, J. K. (2006). Balanced Brand "How To Balance The Stakeholder Forces That Can Make or Break Your Business". San Francisco: Jossey-Bass.

[11]. Kang, J., \& Schrier, T. (2011). The DecisionMaking Process of Tradeshow Exhibitors: The Effects of Social Value, Company Size, and Prior Experience on Satisfaction and Behavioral Intentions. Journal of Convention \& Event Tourism, 65-85.

[12]. Karsono, D. (2016). Bisnis Pameran . Jakarta: Bee Media .

[13]. Kotler, P. (2005). Manajemen Pemasaran (11 ed.). (B. Molan, Penerj.) Jakarta: PT Indeks.

[14]. Kotler, P. (2008). Prinsip-Prinsip Pemasaran (12 ed.). (B. Sabran, Penerj.) Jakarta: Erlangga.

[15]. Kusuma, R. C. (2016). Modul Manajemen Event. Diambil kembali dari http://staffnew.uny.ac.id/upload/197912032015 042001/pendidikan/MODUL\%20MANAJEMEN \%20EVENT.Chusnu.pdf.

[16]. Philip Kotler, H. K. (2019). Marketing 4.0 Bergerak dari Tradisional ke Digital. Jakarta: PT Gramedia Pustaka Utama.

[17]. Pu, B., Xiao, R., \& Du, F. (2019). Influence of Exhibition Promotion on Exhibition Performance: An Empirical Case of Exhibitors in China. IEMB, 272-279.

[18]. Pudjiastuti, W. (2010). Special Event. JAKARTA: PT Elex Media Komputindo.

[19]. Rangkuti, F. (2017). Customer Care Excellence. Jakarta: PT Gramedia Pustaka Utama . 
[20]. Reinhold, M. (2016). Intention to re-exhibit when does it translate to actual trade fair attendance? IfM-HSG, 1-23.

[21]. Salusu , J. (2015). Pengambilan Keputusan Stratejik Untuk Organisasi Publik dan Organisasi Non Profit. JAKARTA: PT Grasindo.

[22]. Setiawan, S. (2011). Loyalitas Pelanggan Jasa. BOGOR: PT Penerbit ITB Press.

[23]. Solihat, A., \& Nugraha. (2020). How Behavior Finance during Pandemi Covid-19. BIEJ, 131137.

[24]. Suara.com. (2020, Juni 3). KEMENPAREKRAF: Industri MICE Berperan Penting Dalam Pendapatan PDB. Dipetik July 29, 2020, dari www.suara.com:

https://www.suara.com/bisnis/2020/06/03/1326

35/kemenparekraf-industri-mice-berperanpenting-dalam-pendapatan-pdb

[25]. Terracciano, A. (2018). The Trading Faces Online Exhibition and Its Strategies of Public Engagement. Human IT, 1-18.

[26]. UFI. (2021, April 8). Trade show organisers and associations join forces to create safe, successful platforms for economic recovery and reconnection. Retrieved April 24, 2021, from https://www.ufi.org: https://www.ufi.org/newsmedia/media-releases/

[27]. Wagdy, A. R. (2019). Measuring The Economic Impact Of The Egyptian Exhibition Industry. Event Management, 23, 347-362.

[28]. Wijaya, T. (2019). Manajemen Kualitas Jasa. Jakarta: PT Indeks.

[29]. Yusuf, A. M. (2014). Metode Penelitian Kuantitatif, Kualitatif dan Penelitian Gabungan. Jakarta: Kencana.

\section{Cite this article as :}

Pesta Elrida Lumbantoruan, Wahyudi David, "Company's Decision on Virtual Exhibition During Covid-19 Pandemic", International Journal of Scientific Research in Science and Technology (IJSRST), Online ISSN : 2395-602X, Print ISSN : 23956011, Volume 8 Issue 4, pp. 207-215, July-August 2021. Available at doi : https://doi.org/10.32628/IJSRST218433 Journal URL : https://ijsrst.com/IJSRST218433 